\title{
Existing Road Performance of the New Development of Sibu Central
}

\author{
Nisa Aqila Bakie and Dr Mastura Bujang \\ University College of Technology Sarawak
}

\begin{abstract}
The proposed development of Sibu Central hinges on the fact that it attracts high number of visitors from all over Sarawak. The development of Sibu Central would definitely improve the surrounding areas in future as Sibu Central will be one of the landmarks for Sibu. This development therefore will automatically generate more road traffic which will affect the performance of the existing road. The performance of the existing road was evaluated by two signalized intersections surrounding the proposed development of Sibu Central. It was carried out in order to determine the current traffic volume data, upon the completion of Sibu Central and 5 years after the development was completed. The road performance of Intersection 1 and Intersection 2 was analysed by using Sidra software. It was found that the existing road was still within the satisfactory performance, as the Level of Service (LOS) was in the range of LOS A until LOS D. This was due to the current traffic volume that was still under the capacity of the existing road which also influenced the satisfactory result for Volume by Capacity (V/C) ratio, average delay and queue length of all directions in Intersection 1 and Intersection 2. This result will not be adequate as the capacity of the road still remains unchanged due to the fact that the traffic volume keeps on increasing every year. The deterioration of the existing road in Intersection 1 and Intersection 2 was established in this study based on the performance of LOS, V/C ratio, average delay and queue length.
\end{abstract}

Key-word: Average Delay, Level of Service (LOS), Sibu, Signalized Intersection, Traffic Volume, Volume by Capacity (V/C) ratio, Queue Length

\section{INTRODUCTION}

Sarawak is the largest state in Malaysia that approximately has $124451 \mathrm{~km}^{2}$ of area which covers 12 divisions from southern to northern regions. This study is located at Sibu, Sarawak because it is regarded as the central region of Sarawak as shown in Figure 1. Sibu has different modes of transportation such as land, water and air, as it is a transit town for people who live in Mukah, Kapit and Sarikei. In Sibu, transportation by bus is quiet preferable by people who stay outside Sibu as the fare is considered reasonable and convenient to access from their various homes. The government has come out with the initiatives to improve the facilities of Sibu Bus Central Station by proposing a new construction of Sibu Central at Jalan Tun Ahmad Zaidi Adruce. The construction of Sibu Central will certainly lead to the development of Sibu as this place will be equipped with several facilities that could attract people to visit Sibu more often.
This study focuses on identifying the traffic volume in the vicinity of the proposed developments and the evaluation of the performance of the existing road before and after the completion of the proposed development. The area will be evaluated from two signalized intersection of Jalan Tun Ahmad Zaidi Adruce. The data and information regarding traffic volume, road geometry and the phasing signal will be collected on site and it will be analysed based on the effects of $\mathrm{V} / \mathrm{C}$ ratio, average delay, queue distance and LOS of the existing road.

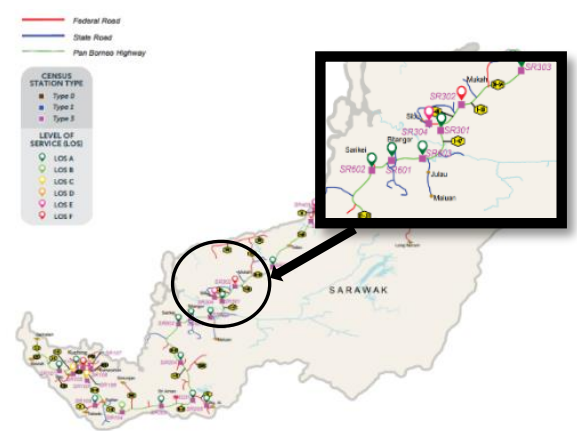

Figure 1: Location of site study [1] 


\section{METHODOLOGY}

\section{LITERATURE REVIEW}

Several factors such as road geometry, condition of the road, high density of the traffic volume and the inefficient traffic signal are really affecting the performance of the roads in Sarawak. According to Naudea et al., [2], geometric design could give significant rate of the incidents that take place at the presence of the curve, roundabout and movement that needs fast action of the steering wheel angle when a vehicle reaches high level of lateral acceleration. Manan, Varhelyi, Celik and Hashim [3] indicate that the poor road conditions, such as slippery surfaces, repaired patches on the road, unevenness, road markings, longitudinal parallel grooves, cobbles, drain covers and gratings are the cause of a significant number of fatal crashes of motorcyclists in Malaysia. Ponnurangama and Umadeviv [4] state that high traffic density and imbalanced supply of transport facilities will take place due to sudden growth in population from 40,000 in 1639 to 7.5 million in 2016 in Chennai, India. Ryabokon [5] also states that the total delay time of all vehicles will increase as the total time of transient intervals between the phases and the timeout for right-of-way of each road users increase, even though the number of phases in traffic light is increased and traffic conflict flow is reduced. This situation could cause discomfort to the road users as they are facing road congestion due to high traffic volume as well as the poor performance of the traffic light. Hartmann and Ling [6] state that the road users have to spend longer time on the road as speed decreases; this situation usually leads to the increase in the consumption of fuel thereby making road users to spend more money on fuelling their vehicles. In addition, the road users are being faced by undue stress while on the road. Hartmann and Ling's study [6] showed that road maintenance in terms of road cleanliness and road evenness were possible factors that contributed to the high indicator weights (0.434 and 0.667) of the level of road users' discomforts. Furthermore, since $15 \%$ of the incidents that do occur on the road were as a result of the poor conditions such as fragile surface of roads, potholes, loose materials, patch repairs and road markings, there is possibility that the condition could have induced the stress experienced by road users [3].
The adopted methodology is summarised in Figure 2. Primary data was collected by conducting surveys in the location of the proposed development in order to evaluate the performance of the traffic conditions. The selection of the site was based on the fact that Sibu Central is a place with high commercial activities (with many shopping malls, apartments and hotels) such that it generates high level of traffic in the area. The collection of the traffic survey was conducted within 3 consecutive days during the morning and the evening peak hours. The road geometry information was collected and used as the database to evaluate the performance of the road. The geometry road information such as the number of lanes, lane and shoulder width, short lane and slip lane width were needed. The signalized intersection phase timing was also taken into account. The performance of the road during base year, upon the completion of proposed development and 5 years after the completion were analysed by using SIDRA software. The analysis was compared and justified based on the $\mathrm{V} / \mathrm{C}$ ratio, average delay, queue distance and Level of Service (LOS) for all directions of the existing road.

\begin{tabular}{|c|c|c|c|}
\hline Selection & $\begin{array}{l}\text { Traffic } \\
\text { Survey }\end{array}$ & Identi & Analysis \\
\hline $\begin{array}{l}\text { of the site } \\
\text { study }\end{array}$ & $\begin{array}{l}\text { Based on } \\
\text { vehicles } \\
\text { category }\end{array}$ & $\begin{array}{l}\text { existing data and } \\
\text { informationTraff } \\
\text { ic survey }\end{array}$ & $\begin{array}{l}\text { - Road performance of base year, upon } \\
\text { completion of proposed developmen and } \\
5 \text { years after completion }\end{array}$ \\
\hline
\end{tabular}

Figure 2: Road performance evaluation process

\section{4}

\section{FIELD STUDIES}

The analysis generally focussed on two signalized intersection within the Sibu area. Intersection 1 involved the movement within Jalan Tunku Abdul Rahman, Jalan Sibu-Bintulu and Jalan Tun Ahmad Zaidi Adruce while Intersection 2 involved the movement within Jalan Tun Ahmad Zaidi Adruce, Jalan Farley and Lorong Sentosa.

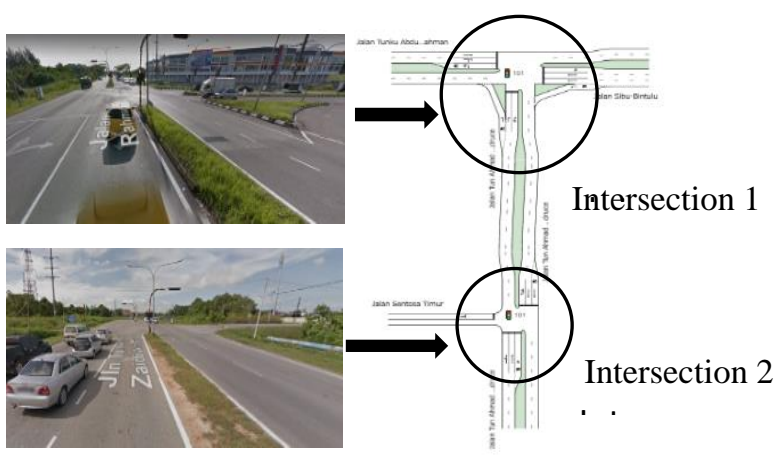

Figure 3: The location of Intersection 1 and Intersection 2 
Intersection 1 was identified as 3-arm signalized intersection and located approximately $3 \mathrm{~km}$ away from the proposed Sibu Central as shown in Figure 3. Jalan Tunku Abdul Rahman is a major road with 3 lanes including short lane while Jalan Sibu Bintulu consists of 4 lanes including short and slip lanes which are connected to Jalan Tun Ahmad Zaidi Adruce and were separated by median at the signalized intersection.

Intersection 2 was identified as 3-arm signalized intersection and located approximately at $0.8 \mathrm{~km}$ away from the proposed Sibu Centrals as shown in Figure 3. Jalan Tun Ahmad Zaidi Adruce is a major road with 3 lanes including short lane for both directions and were separated by median at the signalized intersection.

\section{RESULT AND DISCUSSION}

\subsection{Traffic Volume Data of Base Year (2018)}

The collection of traffic volume data for the morning and the evening sessions is tabulated as in Table 1 and Table 2 for Intersection 1 and Intersection 2, respectively. The traffic volume data was converted to Passenger Car Unit per Hour (PCU/hr.) based on five categories of vehicles: passenger cars, motorcycles, heavy lorries, medium lorries and buses. They were under A Guide on Geometric Design of Roads Manual. The data was referred to the average of the data collected within 3 days and represented as the worst scenarios of this study for the morning and the evening sessions.

Table 1: Traffic volume (PCU/hr.) of intersection 1

\begin{tabular}{|l|c|c|}
\hline \multicolumn{1}{|c|}{$\begin{array}{c}\text { Direction } \\
\text { (Intersection 1) }\end{array}$} & \multicolumn{2}{|c|}{$\begin{array}{c}\text { Traffic Volume } \\
\text { (PCU/hr.) }\end{array}$} \\
\cline { 2 - 3 } Tunku Abdul & Morning & Evening \\
\hline $\begin{array}{l}\text { Jalan Sibu } \\
\text { Rahman to Jalan } \\
\text { Bintulu (Through) }\end{array}$ & 583 & 831 \\
\hline $\begin{array}{l}\text { Jalan Tunku Abdul } \\
\text { Rahman to Jalan Tun } \\
\text { Ahmad Zaidi Adruce } \\
\text { Turn Right) }\end{array}$ & 1015 & 767 \\
\hline $\begin{array}{l}\text { Jalan Tunku Abdul } \\
\text { Rahman to Jalan Tunku } \\
\text { Abdul Rahman (U-Turn) }\end{array}$ & 36 & 28 \\
\hline $\begin{array}{l}\text { Jalan Sibu - Bintulu to } \\
\text { Jalan Tunku Abdul } \\
\text { Rahman (through) }\end{array}$ & 873 & 811 \\
\hline $\begin{array}{l}\text { Jalan Sibu - Bintulu to } \\
\text { Jalan Tun Ahmad Zaidi } \\
\text { Adruce (Turn Left) }\end{array}$ & 491 & 281 \\
\hline $\begin{array}{l}\text { Jalan Sibu - Bintulu to } \\
\text { Jalan Sibu - Bintulu (U- } \\
\text { turn) }\end{array}$ & 65 & 37 \\
\hline
\end{tabular}

\begin{tabular}{|l|l|l|}
\hline $\begin{array}{l}\text { Jalan Tun Ahmad Zaidi } \\
\text { Adruce to Jalan Sibu - } \\
\text { Bintulu (Turn Right) }\end{array}$ & 811 & 771 \\
\hline $\begin{array}{l}\text { Jalan Tun Ahmad Zaidi } \\
\text { Adruce to Jalan Tunku }\end{array}$ & 588 & 543 \\
$\begin{array}{l}\text { Abdul Rahman (Turn } \\
\text { Left) }\end{array}$ & & \\
\hline
\end{tabular}

Table 2: Traffic volume (PCU/hr.) of intersection 2

\begin{tabular}{|l|c|c|}
\hline \multicolumn{1}{|c|}{$\begin{array}{c}\text { Direction } \\
\text { (Intersection 2) }\end{array}$} & \multicolumn{2}{c|}{$\begin{array}{c}\text { Traffic Volume } \\
\text { (PCU/hr) }\end{array}$} \\
\cline { 2 - 3 } Tun Ahmad Zaidi & Morning & Evening \\
\hline $\begin{array}{l}\text { Jalan Farley } \\
\text { Adruce to } \\
\text { (Through) }\end{array}$ & 1281 & 1042 \\
\hline $\begin{array}{l}\text { Jalan Tun Ahmad Zaidi } \\
\text { Adruce To Lorong } \\
\text { Sentosa (Turn Right) }\end{array}$ & 103 & 160 \\
\hline $\begin{array}{l}\text { Jalan Tun Ahmad Zaidi } \\
\text { Adruce To Jalan Tun } \\
\text { Ahmad Zaidi Adruce (U- } \\
\text { Turn) }\end{array}$ & 26 & 65 \\
\hline $\begin{array}{l}\text { Farley to Jalan Tun } \\
\text { Ahmad Zaidi Adruce } \\
\text { (Through) }\end{array}$ & 1049 & 1209 \\
\hline $\begin{array}{l}\text { Farley to Lorong Sentosa } \\
\text { (Turn Left) }\end{array}$ & 113 & 259 \\
\hline Farley to Farley (U-Turn) & 45 & 93 \\
\hline $\begin{array}{l}\text { Lorong Sentosa to Farley } \\
\text { (Turn Right) }\end{array}$ & 422 & 259 \\
\hline $\begin{array}{l}\text { Lorong Sentosa To Jalan } \\
\text { Tun Ahmad Zaidi Adruce } \\
\text { (Turn Left) }\end{array}$ & 125 & 113 \\
\hline
\end{tabular}

As far as the proposed development is concerned, the direction from Jalan Tunku Abdul Rahman to Jalan Tun Ahmad Zaidi Adruce recorded the highest number of traffic volume of 1013 $\mathrm{PCU} / \mathrm{hr}$. in the morning, followed by the direction from Jalan Sibu Bintulu to Jalan Tunku Abdul Rahman of 873 PCU/hr. and 811 PCU/hr. from Jalan Tun Ahmad Zaidi Adruce to Jalan Sibu Bintulu.

For Intersection 2, the highest number of traffic volume recorded was $1281 \mathrm{PCU} / \mathrm{hr}$. from the through movement of Jalan Tun Ahmad Zaidi Adruce to Farley, followed by 1209 PCU/hr. from the direction of Jalan Tun Ahmad Zaidi Adruce to Jalan Tun Ahmad Zaidi Adruce movement and 422 PCU/hr. from Lorong Sentosa to Jalan Tun Ahmad Zaidi Adruce. 
5.2 Traffic Volume Data (Base Year (2018), upon completion of proposed development (2023) and 5 years after completion of proposed development (2027))

The traffic volume data for 2018, 2023 and 2027 for Intersection 1 and Intersection 2 is tabulated in Table 3 and Table 4, respectively. The increasing rate of the traffic volumes in 2023 and 2027 were due to the traffic growth factor and based on the Equation 1, where $\mathrm{r}$ indicates the traffic growth and $\mathrm{N}$ indicates the design year. In this study, the traffic growth is about $23.2 \%$ from 2006 until 2015 which is according to Road Traffic Volume Malaysia (RTVM, 2015) and the design year was taken as 5 and 10 years from the base year. The traffic growth was selected at Durin Ferry-Junction to Sibu as this location was nearer to the site of the study area.

$$
V_{\text {Forecast Year }}=V_{\text {Base Year }}(1+r)^{N} ;
$$

$\mathrm{r}=$ Traffic Growth and $\mathrm{N}=$ Design years

Table 3: Total traffic generated for intersection 1

\begin{tabular}{|l|c|c|c|}
\hline \multicolumn{1}{|c|}{$\begin{array}{c}\text { Direction } \\
\text { (Intersection 1) }\end{array}$} & \multicolumn{3}{|c|}{$\begin{array}{c}\text { Traffic Volume } \\
\text { (PCU/hr.) }\end{array}$} \\
\cline { 2 - 4 } $\begin{array}{l}\text { Jalan Tunku Abdul } \\
\text { Rahman to Jalan Sibu } \\
\text { Bintulu (Through) }\end{array}$ & 831 & 2023 & 2027 \\
\hline $\begin{array}{l}\text { Jalan Tunku Abdul } \\
\text { Rahman to Jalan Tun } \\
\text { Ahmad Zaidi Adruce } \\
\text { (Turn Right) }\end{array}$ & 1015 & 2880 & 8174 \\
\hline $\begin{array}{l}\text { Jalan Tunku Abdul } \\
\text { Rahman to Jalan Tunku } \\
\text { Abdul Rahman (U-Turn) }\end{array}$ & 36 & 102 & 290 \\
\hline $\begin{array}{l}\text { Jalan Sibu - Bintulu to } \\
\text { Jalan Tunku Abdul } \\
\text { Rahman (through) }\end{array}$ & 873 & 2477 & 7030 \\
\hline $\begin{array}{l}\text { Jalan Sibu - Bintulu to } \\
\text { Jalan Tun Ahmad Zaidi } \\
\text { Adruce (Turn Left) }\end{array}$ & 491 & 1395 & 3958 \\
\hline $\begin{array}{l}\text { Jalan Sibu - Bintulu to } \\
\text { Jalan Sibu - Bintulu (U- } \\
\text { turn) }\end{array}$ & 65 & 185 & 526 \\
\hline $\begin{array}{l}\text { Jalan Tun Ahmad Zaidi } \\
\text { Adruce to Jalan Sibu - } \\
\text { Bintulu (Turn Right) }\end{array}$ & 811 & 2302 & 6533 \\
\hline $\begin{array}{l}\text { Jalan Tun Ahmad Zaidi } \\
\text { Adruce to Jalan Tunku } \\
\text { Abdul Rahman (Turn } \\
\text { Left) } 588\end{array}$ & 1669 & 4737 \\
\hline
\end{tabular}

Table 4: Total traffic generated for intersection 2

\begin{tabular}{|l|c|c|c|}
\hline \multicolumn{1}{|c|}{$\begin{array}{c}\text { Direction } \\
\text { (Intersection 2) }\end{array}$} & \multicolumn{3}{|c|}{$\begin{array}{c}\text { Traffic Volume } \\
\text { (PCU/hr.) }\end{array}$} \\
\cline { 2 - 4 } & 2018 & 2023 & 2027 \\
\hline $\begin{array}{l}\text { Jalan Tun Ahmad Zaidi } \\
\text { Adruce Farley } \\
\text { (Through) }\end{array}$ & 1281 & 3636 & 10319 \\
\hline $\begin{array}{l}\text { Jalan Tun Ahmad Zaidi } \\
\text { Adruce To Lorong } \\
\text { Sentosa (Turn Right) }\end{array}$ & 160 & 454 & 1289 \\
\hline $\begin{array}{l}\text { Jalan Tun Ahmad Zaidi } \\
\text { Adruce To Jalan Tun } \\
\text { Ahmad Zaidi Adruce } \\
\text { (U-Turn) }\end{array}$ & 65 & 185 & 526 \\
\hline $\begin{array}{l}\text { Farley to Jalan Tun } \\
\text { Ahmad Zaidi Adruce } \\
\text { (Through) }\end{array}$ & 1209 & 3431 & 9739 \\
\hline $\begin{array}{l}\text { Farley to Lorong } \\
\text { Sentosa (Turn Left) }\end{array}$ & 259 & 736 & 2089 \\
\hline $\begin{array}{l}\text { Farley to Farley } \\
\text { (U-Turn) }\end{array}$ & 93 & 263 & 747 \\
\hline $\begin{array}{l}\text { Lorong Sentosa to } \\
\text { Farley (Turn Right) }\end{array}$ & 422 & 1198 & 3399 \\
\hline $\begin{array}{l}\text { Lorong Sentosa To Jalan } \\
\text { Tun Ahmad Zaidi } \\
\text { Adruce (Turn Left) }\end{array}$ & 125 & 125 & 354 \\
\hline
\end{tabular}

\subsection{The Existing Performance of Road (Base Year (2018), upon completion of proposed development (2023) and 5 years after completion of proposed development (2027))}

The performance of the road was predicted by evaluating the volume by capacity ratio of the road itself. The capacity of the road was based on the roadway, traffic, control and $\mathrm{w}$ weather condition that could influence the traffic movement. In this study, V/C ratio was evaluated for all the movements at Intersection 1 and Intersection 2. The V/C ratio helped to indicate the performance of the road by showing the Level of Service (LOS) for all directions under Highway Capacity Manual (HCM). The road was categorised under LOS F only if the traffic volume was higher than the capacity of the road.

The summary of the LOS for all directions of Intersection 1 and Intersection 2 is shown in Figure 4 and Figure 5, respectively. It was found that the LOS of both intersections was between LOS A until LOS D as the traffic volume collected was under the capacity of the road at 2018. At Intersection 1, the worst LOS was found from the movement of Jalan Sibu Bintulu to Jalan Tunku Abdul Rahman which recorded LOS D. LOS A was 
recorded from Jalan Sibu Bintulu to Jalan Tun Ahmad Zaidi Adruce, and from Jalan Tun Ahmad Zaidi Adruce to Jalan Tunku Abdul Rahman as this direction was provided with the slip lane that reduced the movement conflict. At Intersection 2, all movements were recorded to experience LOS C.

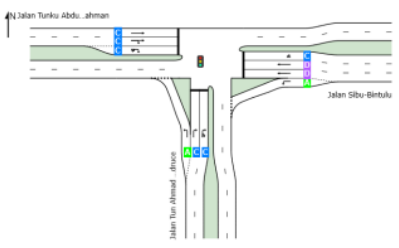

Figure 4: LOS of Intersection 1

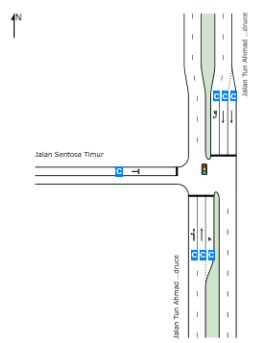

Figure 5: LOS of Intersection 2

As tabulated in Table 5 and Table 6, the result showed the analysis of $\mathrm{V} / \mathrm{C}$ ratio, the average delay and queue distance for Intersection 1 and Intersection 2 during 2018. This analysis was included as part of the road parameters to evaluate and visualize the conditions of the road performance. At Intersection 1, the highest V/C ratio and average delay of 0.602 and 40.3 s respectively were added from the directions of Jalan Sibu Bintulu to Jalan Tunku Abdul Rahman with a queue distance of $50.0 \mathrm{~m}$, while at Intersection 2 the $\mathrm{V} / \mathrm{C}$ ratio of 0.708 contributed to the highest average delay of 36.8s from the directions of Jalan Tun Ahmad Zaidi Adruce to Lorong Sentosa with a queue distance of $68.6 \mathrm{~m}$ in 2018 . The cause of the delay depended on the type of vehicles used, the road geometry, speed limits, and behaviour of the road users as well as the efficiency of the phase timing.

Table 5: Road performance of intersection 1 during 2018

\begin{tabular}{|c|c|c|c|}
\hline Direction & \multicolumn{3}{|c|}{2018} \\
\cline { 2 - 4 } (Intersection 1) & $\begin{array}{c}\text { V/C } \\
\text { ratio }\end{array}$ & $\begin{array}{c}\text { Average } \\
\text { Delay } \\
\text { (s) }\end{array}$ & $\begin{array}{c}\text { Queue } \\
\text { Distance } \\
\text { (m) }\end{array}$ \\
\hline $\begin{array}{l}\text { Jalan Tunku Abdul } \\
\text { Rahman to Jalan Sibu } \\
\text { Bintulu (Through) }\end{array}$ & 0.556 & 21.5 & 101.6 \\
\hline $\begin{array}{l}\text { Jalan Tunku Abdul } \\
\text { Rahman to Jalan Tun } \\
\text { Ahmad Zaidi Adruce } \\
\text { (Turn Right) }\end{array}$ & 0.556 & 21.6 & 93.8 \\
\hline
\end{tabular}

\begin{tabular}{|l|l|l|l|}
\hline $\begin{array}{l}\text { Jalan Tunku Abdul } \\
\text { Rahman to Jalan } \\
\text { Tunku Abdul Rahman }\end{array}$ & 0.556 & 21.6 & 91.1 \\
(U-Turn) & & & \\
\hline $\begin{array}{l}\text { Jalan Sibu-Bintulu to } \\
\text { Jalan Tunku Abdul } \\
\text { Rahman (through) }\end{array}$ & 0.602 & 40.3 & 50.0 \\
\hline $\begin{array}{l}\text { Jalan Sibu-Bintulu to } \\
\text { Jalan Tun Ahmad } \\
\text { Zaidi Adruce (Turn } \\
\text { Left) }\end{array}$ & 0.173 & 3.8 & 16.3 \\
\hline $\begin{array}{l}\text { Jalan Sibu-Bintulu to } \\
\text { Jalan Sibu - Bintulu } \\
\text { (U-turn) }\end{array}$ & 0.097 & 33.7 & 5.6 \\
\hline $\begin{array}{l}\text { Jalan Tun Ahmad } \\
\text { Zaidi Adruce to Jalan } \\
\text { Sibu - Bintulu (Turn } \\
\text { Right) }\end{array}$ & 0.584 & 33.5 & 62.5 \\
\hline $\begin{array}{l}\text { Jalan Tun Ahmad } \\
\text { Zaidi Adruce to Jalan } \\
\text { Tunku Abdul Rahman } \\
\text { (Turn Left) }\end{array}$ & 0.239 & 2.6 & 20.3 \\
\hline
\end{tabular}

Table 6: Road performance of intersection 2 during 2018

\begin{tabular}{|l|c|c|c|}
\hline \multicolumn{1}{|c|}{$\begin{array}{c}\text { Direction } \\
\text { (Intersection 2) }\end{array}$} & \multicolumn{3}{|c|}{2018} \\
\cline { 2 - 4 } & $\begin{array}{c}\text { V/C } \\
\text { ratio }\end{array}$ & $\begin{array}{c}\text { Average } \\
\text { Delay } \\
\text { (s) }\end{array}$ & $\begin{array}{c}\text { Queue } \\
\text { Distance } \\
\text { (m) }\end{array}$ \\
\hline $\begin{array}{l}\text { Jalan Tun Ahmad } \\
\text { Zaidi Adruce to Farley } \\
\text { (Through) }\end{array}$ & 0.802 & 31.3 & 115.8 \\
\hline $\begin{array}{l}\text { Jalan Tun Ahmad } \\
\text { Zaidi Adruce To } \\
\text { Lorong Sentosa (Turn } \\
\text { Right) }\end{array}$ & 0.302 & 28.2 & 27.9 \\
\hline $\begin{array}{l}\text { Jalan Tun Ahmad } \\
\text { Zaidi Adruce To Jalan } \\
\text { Tun Ahmad Zaidi } \\
\text { Adruce (U-Turn) }\end{array}$ & 0.302 & 29.8 & 27.9 \\
\hline $\begin{array}{l}\text { Farley to Jalan Tun } \\
\text { Ahmad Zaidi Adruce } \\
\text { (Through) }\end{array}$ & 0.708 & 31.0 & 70.4 \\
\hline $\begin{array}{l}\text { Farley to Lorong } \\
\text { Sentosa (Turn Left) }\end{array}$ & 0.708 & 36.8 & 68.6 \\
\hline $\begin{array}{l}\text { Farley to Farley } \\
\text { (U-Turn) }\end{array}$ & 0.219 & 33.9 & 13.7 \\
\hline $\begin{array}{l}\text { Lorong Sentosa to } \\
\text { Farley (Turn Right) }\end{array}$ & 0.464 & 29.4 & 49.5 \\
\hline $\begin{array}{l}\text { Lorong Sentosa To } \\
\text { Jalan Tun Ahmad } \\
\text { Zaidi Adruce (Turn } \\
\text { Left) }\end{array}$ & 0.464 & 29.5 & 49.5 \\
\hline
\end{tabular}

The traffic volume was significantly increased during 2023 and 2027, and presented the deterioration of LOS to LOS F to almost all movements as summarized in Figure 6 and Figure 7 for both intersections. This may be due to the additional number of traffic volume while the capacity of the road remains unchanged for both intersections. 

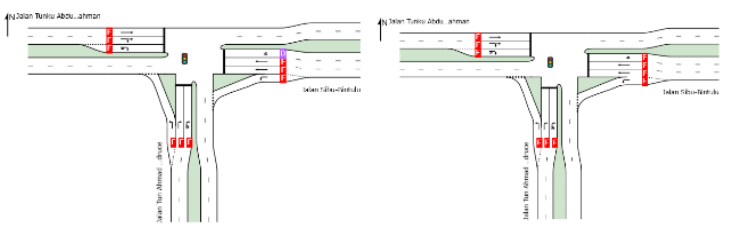

2023

2027

Figure 6: Summary of LOS for Intersection 1

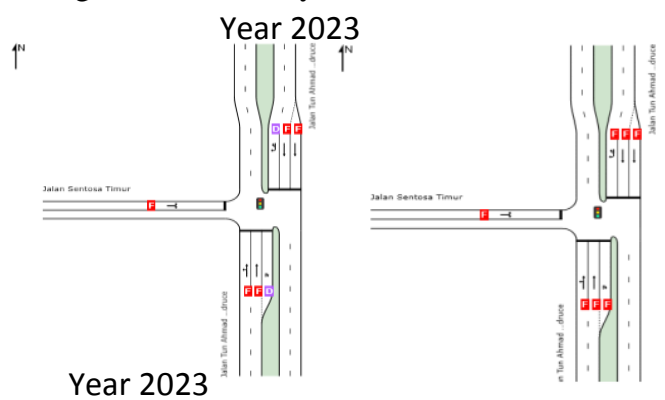

Figure 7: Summary of LOS for Intersection 2

It also revealed the weakening of the average delay and the distance of queue for both intersections. This is because there was tremendous increase of the traffic volume as the capacity and conditions of the road remained unchanged so as to cater for this addition as tabulated in Table 7 and Table 8 for Intersection 1 and Intersection 2 , respectively.

The utmost average delay and queue distance, and $\mathrm{V} / \mathrm{C}$ ratio revealed for Intersection 1 came from the direction of Jalan Sibu Bintulu to Jalan Tunku Abdul Rahman with an average delay of $857 \mathrm{~s}$ and $903 \mathrm{~m}$ queue distance during 2023 and average delay of $3200 \mathrm{~s}, 3223 \mathrm{~m}$ queue distance and $8.080 \mathrm{~V} / \mathrm{C}$ ratio in 2027.

Table 7: Road performance during 2023 and 2027 of intersection 1

\begin{tabular}{|c|c|c|c|c|c|c|}
\hline \multirow[b]{2}{*}{$\begin{array}{c}\text { Direction } \\
\text { (Intersection 1) }\end{array}$} & \multicolumn{3}{|c|}{2023} & \multicolumn{3}{|c|}{2027} \\
\hline & $\begin{array}{l}\mathrm{V} / \mathrm{C} \\
\text { ratio }\end{array}$ & $\begin{array}{l}\text { Avg } \\
\text { Delay } \\
\text { (s) }\end{array}$ & $\begin{array}{l}\text { Queue } \\
\text { Dis } \\
(\mathrm{m})\end{array}$ & $\begin{array}{l}\mathrm{V} / \mathrm{C} \\
\text { ratio }\end{array}$ & $\begin{array}{l}\text { Avg } \\
\text { Delay } \\
\text { (s) }\end{array}$ & $\begin{array}{l}\text { Queue } \\
\text { Dis } \\
(\mathrm{m})\end{array}$ \\
\hline $\begin{array}{l}\text { Jalan Tunku } \\
\text { Abdul Rahman } \\
\text { to Jalan Sibu } \\
\text { Bintulu } \\
\text { (Through) } \\
\end{array}$ & 1.795 & 379 & 1211 & 4.476 & 1574 & 4501 \\
\hline $\begin{array}{l}\text { Jalan Tunku } \\
\text { Abdul Rahman } \\
\text { to Jalan Tun } \\
\text { Ahmad Zaidi } \\
\text { Adruce (Turn } \\
\text { Right) }\end{array}$ & 1.795 & 381 & 897 & 4.476 & 1574 & 4137 \\
\hline $\begin{array}{l}\text { Jalan Tunku } \\
\text { Abdul Rahman } \\
\text { to Jalan Tunku } \\
\text { Abdul Rahman } \\
\text { (U-Turn) }\end{array}$ & 1.795 & 382 & 887 & 4.476 & 1574 & 4013 \\
\hline $\begin{array}{l}\text { Jalan Sibu - } \\
\text { Bintulu to Jalan } \\
\text { Tunku Abdul } \\
\text { Rahman } \\
\text { (through) }\end{array}$ & 2.847 & 857 & 903 & 8.080 & 3200 & 3223 \\
\hline
\end{tabular}

\begin{tabular}{|l|c|c|c|c|c|c|}
\hline $\begin{array}{l}\text { Jalan Sibu- } \\
\text { Bintulu to } \\
\text { Jalan Tun } \\
\text { Ahmad Zaidi } \\
\text { Adruce (Turn } \\
\text { Left) }\end{array}$ & 1.204 & 131 & 442 & 3.010 & 917 & 2809 \\
\hline $\begin{array}{l}\text { Jalan Sibu - } \\
\text { Bintulu to Jalan } \\
\text { Sibu - Bintulu } \\
\text { (U-turn) }\end{array}$ & 0.459 & 37 & 30 & 1.306 & 197 & 190 \\
\hline $\begin{array}{l}\text { Jalan Tun } \\
\text { Ahmad Zaidi } \\
\text { Adruce to Jalan } \\
\text { Sibu- Bintulu } \\
\text { (Turn Right) }\end{array}$ & 2.098 & 523 & 785 & 5.877 & 2208 & 3081 \\
\hline $\begin{array}{l}\text { Jalan Tun } \\
\text { Ahmad Zaidi } \\
\text { Adruce to Jalan } \\
\text { Tunku Abdul } \\
\text { Rahman (Turn } \\
\text { Left) }\end{array}$ & 1.226 & 130 & 519 & 4.884 & 1758 & 3804 \\
\hline
\end{tabular}

The utmost average delay and queue distance of Intersection 2 came from the direction of Jalan Tun Ahmad Zaidi Adruce to Lorong Sentosa with an average delay of 1090 s and $1707 \mathrm{~m}$ queue distance during 2023 and average delay of 3883 s, $5885 \mathrm{~m}$ queue distance and 9.501 V/C ratio in 2027.

Table 8: Road performance during the year 2023 and 2027 of intersection 2

\begin{tabular}{|c|c|c|c|c|c|c|}
\hline \multirow{2}{*}{$\begin{array}{c}\text { Direction } \\
\text { (Intersection 2) }\end{array}$} & \multicolumn{3}{|c|}{2023} & \multicolumn{3}{|c|}{2027} \\
\hline & $\begin{array}{l}\mathrm{V} / \mathrm{C} \\
\text { ratio }\end{array}$ & $\begin{array}{c}\text { Avg } \\
\text { Delay } \\
\text { (s) }\end{array}$ & $\begin{array}{c}\text { Queue } \\
\text { Dis } \\
(\mathrm{m})\end{array}$ & $\begin{array}{l}\mathrm{V} / \mathrm{C} \\
\text { ratio }\end{array}$ & $\begin{array}{c}\text { Avg } \\
\text { Delay } \\
\text { (s) }\end{array}$ & $\begin{array}{l}\text { Queue } \\
\text { Dis } \\
(\mathrm{m})\end{array}$ \\
\hline $\begin{array}{l}\text { Jalan Tun } \\
\text { Ahmad Zaidi } \\
\text { Adruce to } \\
\text { Farley } \\
\text { (Through) }\end{array}$ & 2.417 & 669 & 1398 & 6.458 & 2503 & 5406 \\
\hline $\begin{array}{l}\text { Jalan Tun } \\
\text { Ahmad Zaidi } \\
\text { Adruce To } \\
\text { Lorong } \\
\text { Sentosa (Turn } \\
\text { Right) }\end{array}$ & 0.857 & 41 & 113 & 2.434 & 682 & 1293 \\
\hline $\begin{array}{l}\text { Jalan Tun } \\
\text { Ahmad Zaidi } \\
\text { Adruce To } \\
\text { Jalan Tun } \\
\text { Ahmad Zaidi } \\
\text { Adruce (U- } \\
\text { Turn) }\end{array}$ & 0.857 & 43 & 113 & 2.434 & 683 & 1293 \\
\hline $\begin{array}{l}\text { Farley to } \\
\text { Jalan Tun } \\
\text { Ahmad Zaidi } \\
\text { Adruce } \\
\text { (Through) }\end{array}$ & 3.347 & 1085 & 1751 & 9.501 & 3877 & 6037 \\
\hline $\begin{array}{l}\text { Farley to } \\
\text { Lorong } \\
\text { Sentosa (Turn } \\
\text { Left) }\end{array}$ & 3.347 & 1090 & 1707 & 9.501 & 3883 & 5885 \\
\hline $\begin{array}{l}\text { Farley to } \\
\text { Farley } \\
\text { (U-Turn) }\end{array}$ & 0.618 & 37 & 44 & 1.755 & 380 & 470 \\
\hline $\begin{array}{l}\text { Lorong } \\
\text { Sentosa to } \\
\text { Farley (Turn } \\
\text { Right) }\end{array}$ & 1.609 & 313 & 83 & 4.565 & 1647 & 3297 \\
\hline
\end{tabular}




\begin{tabular}{|l|l|l|l|l|l|l|}
\hline Lorong & & & & & & \\
Sentosa To \\
Jalan Tun \\
$\begin{array}{l}\text { Ahmad Zaidi } \\
\text { Adruce (Turn } \\
\text { Left) }\end{array}$ & 1.609 & 313 & 83 & 4.565 & 1647 & 3297 \\
\hline
\end{tabular}

\subsection{Conclusion}

The forecasted number of traffic volume is evaluated in order to foresee the conditions of the existing road during 2023 and 2027 of two signalized intersection that will be influenced by the proposed development of Sibu Central. The increasing number of traffic volume beyond the capacity of the road has been confirmed to be the cause of the traffic congestion. The declination of the effectiveness of signal timing could lead to the overflow of the queued vehicles as the roads need to cater for the residual traffic that was unable to be discharged from previous cycles. This condition causes the lengthy average delay and the distance of queue during 2023 and 2027 in the vicinity of the proposed development. The study can be enhanced by proposing suggestions to upgrade the road geometry of the impacted area and thus increase the capacity of the road. This can be done by undertaking the Traffic Impact Assessment (TIA) of the study area to access the performance of the road after upgrading the conditions of the road.

\section{References}

[1] 2015 Road Traffic Volume Malaysia (RTVM). Ministry of Work Malaysia.

[2] Naude,C.,et. al., (2017). Acquisition and analysis of road incidents based on vehicle dynamics. Accident Analysis and Prevention.

[3] Manan, M.M.A., Varhelyi, Andras., Celik, A.K., \& Hashim, H.H. (2017). Road characteristics and environment factors associated with motorcycle fatal crashes in Malaysia. IATSS Research (International Association of Traffic and Safety Sciences), 42, 207-220.

[4] Ponnurangama, P., \& Umadevib., D.G. (2016). Traffic Impact Analysis (TIA) for Chennai IT Corridor. Transportation Research Procedi, 17. 234 -243 .

[5]Ryabokon,Y. (2017). The Method of Determining the Number of Phases in the Traffic Light Cycle on the Allowable Intensity of Conflicting Flows. Transportation Research Procedia, 20. 571 - 577.

[6] Hartmann, A., \& Ling, F.Y.Y., (2015). Value creation of road infrastructure networks: A structural equation approach. Journal of Traffic and 